ISSN: 2362-1303 (Paper) | eISSN: 2362-1311(Online)

JOURNAL OF ADVANCED ACADEMIC RESEARCH (JAAR)

\title{
Effect of Bank Lending on Inflation in Nepal
}

\section{Neelam Timsina Dhungana ${ }^{1}$ and Radhe Shyam Pradhan ${ }^{2}$}

${ }^{1} \mathrm{PhD}$ Scholar, Mewar University, Chittorgarh, Rajasthan, India

${ }^{2}$ Research Supervisor, Professor, Tribhuvan University, Kirtipur.

\section{Corresponding Author}

Neelam Timsina Dhungana

Email: neelam@nrb.org.np

\section{ABSTRACT}

This study examines the effect of commercial bank lending on inflation in Nepal. The study has conducted correlation and regression analysis using panel data of twenty four commercial banks during the period of 1996 -2015. The empirical results show that bank lending has positive effect on the inflation in Nepal. The study implies that central bank willing to contain inflation should curtail excessive bank lending on unproductive and speculative sector.

\section{KEYWORDS}

Inflation, Bank Lending, Regression

JEL Classification: E31, G21, C33

\section{INTRODUCTION}

Commercial banks perform the act of financial intermediary that gather money from the excess sector in the form of deposits and lend it to various sectors of the economy. Lending is one of the major functions of banking institution. Through this work, banks affect the economic growth and stability in the economy. Although credit growth can spur investment and economic activity, an excessive growth in credit can impact the price stability as well as stability of the financial system by increasing prudential risks at the micro and macro levels (Igan and Pinheiro, 2011).

Inflation is a consistent increase in price. To some extent inflation is good for promoting economic growth. But if it crosses the limit, excessive inflation threatens the economic growth, stability and overall economy. High inflation distorts the optimal allocation of resources and distorts growth, weakens the external competitiveness, lowers the domestic financial savings among others (RBI, 2014).

Therefore, main objective of monetary policy in either developed or developing countries is price stability. Price stability is the foundation of economic stability. Central bank always wishes to contain inflation within a certain target. In many countries, today, inflation targeting regime is being adopted. In other countries, where there is no direct inflation targeting regime, the main objective of their monetary policy is price stability.

There are several factors of rising inflation. They can be categorized in demand side and supply side factors. In demand side factors, excessive flow of bank lending 
(private sector lending) to unproductive sector, increase in money supply, net foreign assets, liquidity of the banking sector are the major factors. From supply point of view, exchange rate change, structural rigidities, cartelling, syndicating, power shortage, exchange rate regime, low production etc are the major factors affecting inflation. Here in the case, the focus is concerned with bank lending i.e private sector credit.

Private sector credit has great implication on inflation. If commercial banks provide more credit to private sector, there are two consequences. If such credit can be utilized in productive sector like agriculture, hydroelectricity, tourism and other industries and production increases, then excessive credit flows is absorbed by the production. In this case inflation does not increase. If excessive credit flows done by the banks to the unproductive sectors such as real estate sector, share, gold and other personal consumption, then it increases the price. As more money chasing the few goods, it is natural to increase price. Increase in price results in deterioration of export competitiveness and it declines the terms of trade resulting in external sector instability. On the other hand price increase caused by the excessive bank credit balloons the real estate and share price unnecessarily, which if burst, systemic risk arises. Excessive increase in real estate, share price leads to deterioration of credit quality, bank balance sheet, and increase in credit default and credit risk. Therefore price stability is the foundation of financial sector stability also. As a whole economic stability depends upon price stability and price stability mostly depends upon private sector credit, which is the important monetary aggregate.

Private sector credit is one of the ingredients of domestic assets and money supply. Central bank uses to target private sector credit also to keep money supply and inflation within a certain target. Therefore, while we talk about monetary transmission process, we should not forget to study the relationship between private sector credit and inflation which in turn guide the monetary policy measures to be taken by the central bank.

In Nepal, Nepal Rastra Bank, the central bank of Nepal sets the inflation indicator within a target level, though monetary policy regime is not inflation targeting rather it is monetary aggregate targeting. In the recent days, empirical analysis on private sector credit-price relationship has got greater attention, since there is a move to assign the single objective to the central bank. Among the possible objectives of monetary policy, price stability is the single most important objective. Nepal Rastra Bank Act 2002 has also mentioned that NRB's main objective is price stability. Also, the monetary policy has price stability objective. Assignment of price stability as the single objective of monetary policy pivots on the empirical strength of private sector credit-inflation relationship. In Nepal, inflation is mainly affected by supply side factors, such as Indian inflation, exchange rate peg with India, exchange rate depreciation, power shortage, uncertainty in government policies and syndicating. Generally, it is said that the effect of demand side factor, i.e. money supply is quite low. However, it cannot be ignored the fact that, excessive increase in bank lending to unproductive sector, and resulting increase in money supply has, of course, some pressure on inflation. Therefore, in analyzing the monetary transmission process, the study of impact of bank lending on inflation should be analyzed properly. 
There are several studies that have been carried out on this topic in foreign countries but in case of Nepal, there are not enough studies on this topic especially based on recent panel data and method. Thus, this study acts as the basis for further investigation in the area of bank lending and inflation in Nepal. This study attempts to identify whether the bank lending affects inflation. Thus the main objective of this study is to assess the effect of bank lending on inflation as well as to suggest ways of improving the bank lending to achieve price stability in Nepal.

\section{THEORETICAL FRAMEWORK}

Bank lending has key role in promoting economic growth. However, there is a risk of increasing inflation by irrational bank lending. On the one hand, excessive bank lending to especially unproductive and speculative sector leads to the unnecessary increase in money supply and inflation. On the other hand, very low and restrictive bank lending leads to curtail in production and thus gives rises to increase in inflation.

The relationship between the quantity of money in circulation and the general price level has long been established by the quantitative theory of money of Friedman saying that the price increase comes from an increase in the money stock (Johnson, 2015). Money supply is affected by bank lending and thus bank lending is supposed to affect inflation. In quantity theory of money of classical economists, economy is always in full employment level and there is direct and reciprocal relationship between money supply and price of goods and services. It means, increase in money supply results in the increase in price level in the same ratio. Monetarists including Milton Friedman opined that inflation is always and everywhere a monetary phenomenon. Inflation occurs when there is too much money chasing too few goods. Keynesian theory argues that economy is not in full employment level. Therefore, increase in money supply leads to an increase in output and price also. Though there is relation between the money supply and inflation but this is not direct and reciprocal.

The contractionary monetary policies affect investment in two ways: they increase the real cost of bank lending; and, by increasing interest rates, they increase the opportunity cost of retained earnings (Korkmaz, 2015). Both mechanisms raise the user cost of capital and lead to a reduction in investment (Serven and Solimano, 1992).Credit restrictions do reduce effective supply in the real world (e.g. through investment). And if these effects are bigger than the effects of tight credit on demand, inflationary pressures will result (Blinder, 1987).

\section{LITERATURE REVIEW}

Review of literature on effect of bank lending on inflation is shown in table 1.

Table 1: Review of literature on effect of bank lending on inflation

\begin{tabular}{|l|l|}
\hline Study & Major Findings \\
\hline
\end{tabular}




\begin{tabular}{|l|l|}
\hline $\begin{array}{l}\text { Serven and } \\
\text { Solimano (1992) }\end{array}$ & $\begin{array}{l}\text { Credit restrictions raise the user cost of capital and lead to a } \\
\text { reduction in investment }\end{array}$ \\
\hline $\begin{array}{l}\text { Antzoulatos and } \\
(1996) \\
\text { Ludvigson (1999) }\end{array}$ & $\begin{array}{l}\text { An increase in bank lending to private sector is positively } \\
\text { related to an increase in consumption. There is a positive nexus } \\
\text { between inflation and bank credit to the private sector. }\end{array}$ \\
\hline $\begin{array}{l}\text { Bacchetta and } \\
\text { Gerlach (1997) }\end{array}$ & $\begin{array}{l}\text { Decline in credit extension appears to be negatively related to } \\
\text { the growth of consumption and thereby to inflation also. }\end{array}$ \\
\hline $\begin{array}{l}\text { Huang and Xu, and Corsetti } \\
\text { et al., (1999) }\end{array}$ & $\begin{array}{l}\text { Empirical study shows that excessive private sector credit may } \\
\text { result in inflation. }\end{array}$ \\
\hline Debelle (2004) & $\begin{array}{l}\text { Uncontrolled bank credit to the private sector may give rise to } \\
\text { inflationary pressures which may weaken the effeciency of } \\
\text { monetary policy. }\end{array}$ \\
\hline Yunus (2004) & $\begin{array}{l}\text { Using a VAR approach and Granger Causality Test, found in } \\
\text { her study that the private sector credit has no real effect on } \\
\text { economic growth but is inflationary. }\end{array}$ \\
\hline Korkmaz (2015) & $\begin{array}{l}\text { The contractionary monetary policies affect investment in two } \\
\text { ways: they increase the real cost of bank lending; and, by } \\
\text { increasing interest rates, they increase the opportunity cost of } \\
\text { retained earnings }\end{array}$ \\
\hline
\end{tabular}

Most economists have consensus that monetary policy should be primarily concerned with the pursuit of price stability (Mboweni, 2000, van der Merwe, 2004, Genberg, 2002, White, 2006). However, there is no similar opinion among the economists on the appropriate and effective ways to achieve this objective. At the same time, a number of countries have adopted inflation targeting as their monetary policy objective. New Zealand was the first country to adopt inflation targeting in 1990 as part of economic reforms following a period of poor economic performance (World Bank, 2004).

Many studies on inflation targeting in various developed and developing countries indicate that this regime has played a vital role in containing inflation and stabilizing interest rates. Benefits of inflation targeting regimes are lower inflation rates and lower inflation expectations; lower nominal interest rates as a result of the lower inflation expectations; and credible monetary policy (Bernanke et al., 1999: 297). While previous studies have analyzed the impact of several macroeconomic variables on inflation (Smal, 1998; Bernanke et al., 1999 and Goohoon et al., 2006), the study on the impact of bank lending (private sector credit) on inflation has not received adequate attention. Excessive private sector credit to unproductive sector is a macroeconomic issue in the sense that it increases the economy's vulnerability to external financial pressures, where would deteriorate the terms of trade i.e. decline in such as a fall in anticipated exports prices can impair the capacity of local firms to service their debt. Debelle (2004) points out that uncontrolled bank credit to the private 
sector may give rise to inflationary pressures that will undermine the effectiveness of monetary policy. In the studies done for the UK, Nordic countries and the Netherlands, Debelle (2004) has found that excessive private sector credit may result in inflation. This argument is further supported by a number of economists (for example Huang and Xu, 1999 and Corsetti et al., 1999). Studies by Antzoulatos (1996) and Ludvigson (1999) on OECD countries show that an increase in bank lending to private sector is positively related to an increase in consumption. These two studies provide evidence that there is a positive relationship between inflation and bank credit to the private sector. Their argument is further supported by Bacchetta and Gerlach (1997), who found that decline in credit extension, appears to be negatively related to the growth of consumption. Yunus (2004 ) using a VAR approach and Granger Causality Test, found that the private sector credit has no real effect on economic growth but is inflationary.

\section{STRUCTURE AND PATTERN OF BANK LENDING AND INFLATION IN NEPAL}

\section{Structure and pattern of bank lending}

Lending is key to bank business and it is the major source of profit. It is also important because, monetary instruments are being implemented by affecting bank lending. Therefore, the analysis of bank lending is of crucial importance. Table 2 shows the structure and pattern of lending in sample banks.

Table 2 shows that lending varied widely from one bank to another. Table shows that Rastriya Banijya Bank (RBB) has the highest average lending of Rs. 75774 million followed by Agricultural Development Bank Nepal (ADBN) (Rs. 72216 million), Nepal Investment Bank Limited (NIBL) (Rs. 67033 million), Nepal Arab Bank Limited (NABIL) (Rs. 66996 million), Everest Bank Limited (EBL) (Rs. 54884 million), Nepal Bank Limited (NBL) (Rs. 53241 million), HBL (Rs. 53124 million), Global Bank Limited (GBL) (Rs. 49321 million), Nepal Industrial and Commercial Bank (NICB) (Rs. 42042 million),Nepal State Bank of India (NSBI) (Rs. 39667 million), Siddhartha Bank Limited (SBL) (Rs. 36382 million), Machhapuchhre Bank Limited (MBL) (Rs. 33770 million), Prime Commercial Bank Limited (PCBL) (Rs. 33077 million), Bank of Kathmandu (BOK) (Rs. 31795 million), Laxmi Bank Limited (LXBL) (Rs. 29414 million), Citizen Bank Limited (CBL) (Rs. 29095 million, Standard Chartered Bank Nepal (SCBN) (Rs. 27986 million), Sunrise Bank Limited (SNBL) (Rs. 27348 million), Kumari Bank Limited (KBL) (Rs. 27024 million), Nepal Merchant Bank (NMB) (Rs. 26819 million), Nepal Bangladesh Bank Limited (NBBL) (Rs. 25440 million), Nepal Commerce and Credit Bank (NCCB) (Rs. 21268 million), Lumbini Bank Limited (LBL) (Rs. 17240 million) and Grand Bank Limited GRBL (Rs. 9566 million). The average lending computed across the year is fluctuated widely over a period of time. It increased from Rs. 4827 million in 1996/97 to Rs. 39605 million in 2015.

As per the Table 2, total lending varies widely within the individual banks also. It increased from Rs. 14856 million in 1996 to Rs. 53241 million in 2015 for NBL, from Rs. 18405 million in 1996 to Rs. 75774 million in 2015/16 for RBB, from Rs. 
4306 million to Rs. 66996 million for NABIL, from Rs. 1703 million to Rs. 67033 million for NIBL, from Rs. 3131 million to Rs. 27986 million for SCBNL, from Rs. 2891 million to Rs.53124 million for HBL, from Rs. 1177 million to Rs. 39667 million for NSBI, from Rs. 676 million to Rs. 25440 million for NBBL, from Rs. 49 million to Rs. 54884 million for EBL, from Rs. 1075 million to Rs. 31795 million for BOK.

Total lending increased from Rs. 297 million in 1997 to Rs. 21268 million in 2015 for NCC, from Rs. 472 million in 1999 to Rs. 17240 million in 2015 for LBL, from Rs. 481 million in 1999 to Rs. 42042 million in 2015 for NIC, from Rs. 499 million in 2001 to Rs. 33770 million in 2015 for MPL, from Rs. 264 million in 2001 to Rs. 27024 million in 2015 for KBL, from Rs. 124 million in 2002 to Rs. 29414 million in 2015 for LXBL, from Rs. 629 million in 2003 to Rs. 36382 million in 2015 for SBL, from Rs. 34225 million in 2007 to Rs. 72216 million in 2015 for ADBN, from Rs. 2597 million in 2007 to Rs. 49321 million in 2015 for GBL, from Rs. 2047 million in 2007 to Rs. 29095 million in 2015 for CBL and from Rs. 5154 million in 2008 to Rs. 33077 million in 2015 for PCBL. Similarly, the total lending of SNBL increased from Rs. 4045 million to Rs. 27348 million during the period of 2008 and 2015, which increased from Rs. 3691 million to Rs. 9566 million for GRBL and from Rs. 2010 million to Rs. 26819 million for NMB 
Table 2 : Structure and pattern of lending of commercial banks from year 1996 to 2015

(This table shows the total lending (in million Rs.) of 24 sample banks associated with 369 observations. The mean value measures the average lending of individual sample banks and all sample banks for particular year and standard deviation measures the variability in lending.)

\begin{tabular}{|c|c|c|c|c|c|c|c|c|c|c|c|c|c|c|c|c|c|c|c|c|c|c|}
\hline Bank & 1996 & 1997 & 1998 & 1999 & 2000 & 2001 & 2002 & 2003 & 2004 & 2005 & 2006 & 2007 & 2008 & 2009 & 2010 & 2011 & 2012 & 2013 & 2014 & 2015 & Mean & Std De \\
\hline NBL & 14856 & 18069 & 19472 & 22395 & 22864 & 21729 & 20756 & 19078 & 19108 & 17456 & 12180 & 13378 & 15481 & 19261 & 25074 & 26638 & 29551 & 37844 & 41191 & 53241 & 23481 & 9933 \\
\hline RBB & 18405 & 18922 & 22405 & 26340 & 29141 & 28081 & 28184 & 27970 & 26514 & 28614 & 26864 & 25215 & 27354 & 31464 & 35617 & 36792 & 40346 & 48981 & 60792 & 75774 & 33189 & 13750 \\
\hline NABIL & 4306 & 4625 & 5295 & 5812 & 7324 & 8173 & 7072 & 7997 & 8635 & 11078 & 13021 & 15657 & 21515 & 27817 & 32903 & 38766 & 42732 & 47523 & 55830 & 66996 & 21654 & 18818 \\
\hline NIBL & 1703 & 1729 & 1678 & 1422 & 2071 & 2386 & 2693 & 5873 & 7174 & 10295 & 13007 & 17482 & 27146 & 36250 & 40690 & 41665 & 42510 & 47369 & 53093 & 67033 & 21163 & 20667 \\
\hline SCBNL & 3131 & 3582 & 4171 & 4693 & 4957 & 5839 & 5676 & 6029 & 6662 & 8214 & 8905 & 10538 & 13355 & 13119 & 15932 & 17698 & 18376 & 23126 & 26317 & 27986 & 11415 & 7587 \\
\hline HBL & 2891 & 3382 & 4276 & 5372 & 7423 & 8837 & 9674 & 10894 & 13082 & 13245 & 15516 & 17672 & 19985 & 25292 & 28977 & 31657 & 34283 & 39649 & 44400 & 53124 & 19481 & 14393 \\
\hline NSBI & 1177 & 1721 & 2415 & 2930 & 3560 & 4091 & 4529 & 4761 & 5491 & 6619 & 8060 & 9847 & 12575 & 15465 & 17887 & 21657 & 26404 & 29147 & 35061 & 39667 & 12653 & 11535 \\
\hline NBBL & 676 & 1200 & 1958 & 3259 & 4612 & 7022 & 7969 & 8363 & 9996 & 8740 & 9011 & 8303 & 8420 & 8508 & 8860 & 9944 & 10673 & 12920 & 18825 & 25440 & 8735 & 5585 \\
\hline EBL & 49 & 322 & 868 & 1355 & 2270 & 2964 & 3970 & 5031 & 6117 & 7914 & 10124 & 14059 & 18814 & 24366 & 28130 & 31535 & 36376 & 44008 & 47956 & 54884 & 17056 & 17242 \\
\hline BOK & 1075 & 1336 & 1282 & 1812 & 2995 & 4275 & 4840 & 4913 & 6050 & 6167 & 7525 & 9664 & 12693 & 14895 & 16847 & 17248 & 18064 & 21806 & 26974 & 31795 & 10613 & 8830 \\
\hline $\mathrm{NCC}$ & & 297 & 1272 & 1524 & 1937 & 2894 & 2937 & 3322 & 4418 & 5934 & 5837 & 5084 & 5085 & 7142 & 8373 & 9217 & 12868 & 15920 & 17846 & 21268 & 7009 & 5798 \\
\hline LBL & & & & 472 & 922 & 1793 & 2295 & 2627 & 3207 & 3817 & 4315 & 4938 & 5366 & 5680 & 5480 & 6211 & 6979 & 9175 & 14247 & 17240 & 5574 & 4331 \\
\hline NIC & & & & 481 & 1659 & 2573 & 2329 & 2528 & 3729 & 4895 & 6883 & 9108 & 11447 & 13889 & 12906 & 15149 & 17460 & 32241 & 37301 & 42042 & 12742 & 12491 \\
\hline MPL & & & & & & 499 & 681 & 1494 & 2542 & 5051 & 6033 & 7281 & 8881 & 12957 & 14934 & 14711 & 16023 & 21634 & 29220 & 33770 & 11714 & 9904 \\
\hline KBL & & & & & & 264 & 1120 & 2144 & 3709 & 5519 & 6918 & 9011 & 11449 & 14682 & 14875 & 14898 & 17809 & 20083 & 22797 & 27024 & 11487 & 8001 \\
\hline LXBL & & & & & & & 124 & 764 & 1701 & 2701 & 4274 & 6528 & 9784 & 13446 & 14732 & 15263 & 15848 & 19143 & 21865 & 29414 & 11113 & 8577 \\
\hline SBL & & & & & & & & 629 & 1568 & 2635 & 3869 & 6320 & 9481 & 13505 & 16859 & 18398 & 20115 & 37844 & 27577 & 36382 & 15014 & 12248 \\
\hline ADBN & & & & & & & & & & & & 34225 & 36585 & 38271 & 39375 & 40389 & 45338 & 54959 & 62455 & 72216 & 47090 & 12429 \\
\hline GBL & & & & & & & & & & & & 2597 & 5058 & 9149 & 12139 & 12762 & 20410 & 26832 & 42555 & 49321 & 20091 & 15539 \\
\hline CBL & & & & & & & & & & & & 2047 & 4788 & 8196 & 10906 & 12437 & 14326 & 17684 & 23106 & 29095 & 13620 & 8142 \\
\hline PCBL & & & & & & & & & & & & & 5154 & 9817 & 14102 & 17070 & 19160 & 21736 & 27815 & 33077 & 18491 & 8552 \\
\hline SNBL & & & & & & & & & & & & & 4045 & 8907 & 12147 & 12369 & 14597 & 18335 & 20846 & 27348 & 14824 & 6800 \\
\hline GRBL & & & & & & & & & & & & & 3691 & 6456 & 7501 & 9034 & 11382 & 14322 & 14677 & 9566 & 9578 & 3549 \\
\hline NMB & & & & & & & & & & & & & 2010 & 5010 & 7508 & 10815 & 11135 & 15880 & 0135 & 26819 & 12414 & 7669 \\
\hline Mean & 4827 & 5017 & & 599 & & & & & & & & & & & & & & & & 3960 & & \\
\hline Std Dev & & 0002 & ras & & 8745 & 7889 & בנבתו & 1000 & | & 6402 & | & & Tous & 50,4 & 2047 & 10512 & 11350 & 2500 & 14757 & 18040 & & \\
\hline
\end{tabular}


Figure 1 indicates that total lending curve is in increasing trends until 2015. Moreover, average assets has been increased from Rs. 4827 million in 1996/97 to Rs. 39605 billion in 2015.

(The figure shows the pattern of total lending for all sample banks from 1996 to 2015. The figure has been drawn on the basis of the mean periodic lending).

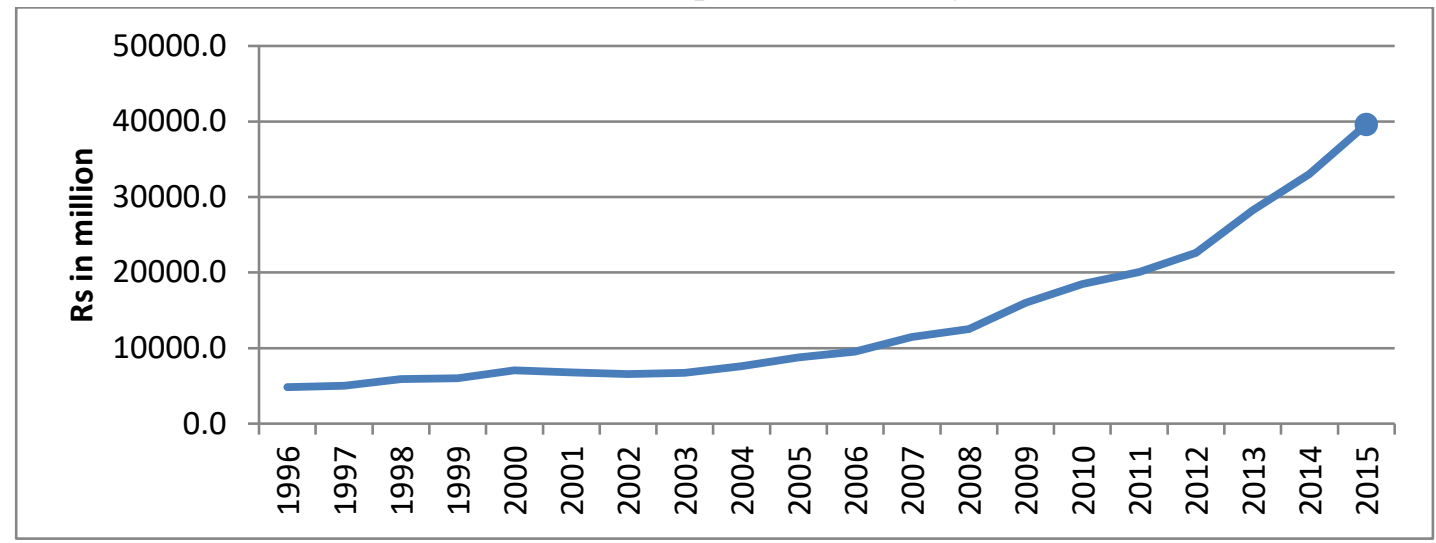

Figure 1: Pattern of lending of commercial banks from year 1996 to 2015

Trend and pattern of macroeconomic variables (economic growth and inflation in Nepal)

As this study attempts to analyze the impact of bank lending on inflation in Nepal, it is necessary to analyze the trend and pattern of inflation (Inf) during the study period. Table 3 shows economic growth and inflation during the period of 1996 to 2015.

Table 3 shows that nominal GDP was Rs. 248913 million which increased to Rs. 2124650 million in 2015. The GDP growth was 12.7 percent in 1997, which stood at 9.4 percent in 2015. Average GDP growth rate was 12 percent during the study period. With regard to inflation, it was fluctuating in different years. Inflation rate was 8.1 percent in 1997 which remained 7.2 percent in 2015. The average inflation rate was 7.4 percent in the study period. Figure 2 shows the trend and pattern of economic growth and inflation in Nepal during the review period.

Table 3: Economic growth and inflation in Nepal 


\begin{tabular}{|c|c|c|c|c|}
\hline \multirow[t]{2}{*}{ Year } & \multicolumn{2}{|l|}{ NGDP } & \multicolumn{2}{|r|}{ Inf } \\
\hline & ( $R$ s in millingn) & Growth $(\%)$ & (lndex) & Growth $(\%)$ \\
\hline 1996 & 248913 & & 72.4 & \\
\hline 1997 & 280513 & 12.7 & 78.3 & B.1 \\
\hline 1998: & 300845 & 7.2 & 84.8 & B.3 \\
\hline 1999 & 342036 & 13.7 & 94.4 & 11.4 \\
\hline 2000 & $37948 \mathrm{~B}$ & 10.9 & 97.7 & 3.5 \\
\hline 2001 & 441519 & 16.3 & 100.0 & 2.4 \\
\hline 2002 & 459443 & 4.1 & 102.9 & 2.9 \\
\hline 2003 & 492231 & 7.1 & 107.8 & 4.8 \\
\hline 2004 & 536749 & 9.0 & 112.1 & 4.0 \\
\hline 2005 & 589412 & 9.8 & 117.2 & 4.5 \\
\hline 2006 & 654084 & 110 & 126.5 & B.o \\
\hline 2007 & 727827 & 11.3 & 134.6 & 6.4 \\
\hline 2008 & B15658 & 12.1 & 145.0 & 7.7 \\
\hline 2009 & 988272 & 21.2 & 164.2 & 13.2 \\
\hline 2010 & 1.92774 & 20.7 & 181.4 & 10.5 \\
\hline 2011 & 1374953 & 15.3 & 198:9 & 9.7 \\
\hline 2012 & 1536000 & 11.7 & 215.4 & B. 3 \\
\hline 2013 & 1701194 & $10 . \mathrm{B}$ & 236.7 & 9.9 \\
\hline 2014 & 1941623 & 14.1 & 258.2 & 9.1 \\
\hline 2015 & 2124650 & 9.4 & 276.8 & 7.2 \\
\hline Mean & 856409.2 & 12.0 & 145.3 & 7.4 \\
\hline Std Dev & 587473.6 & 4.3 & 62.3 & 3.0 \\
\hline
\end{tabular}

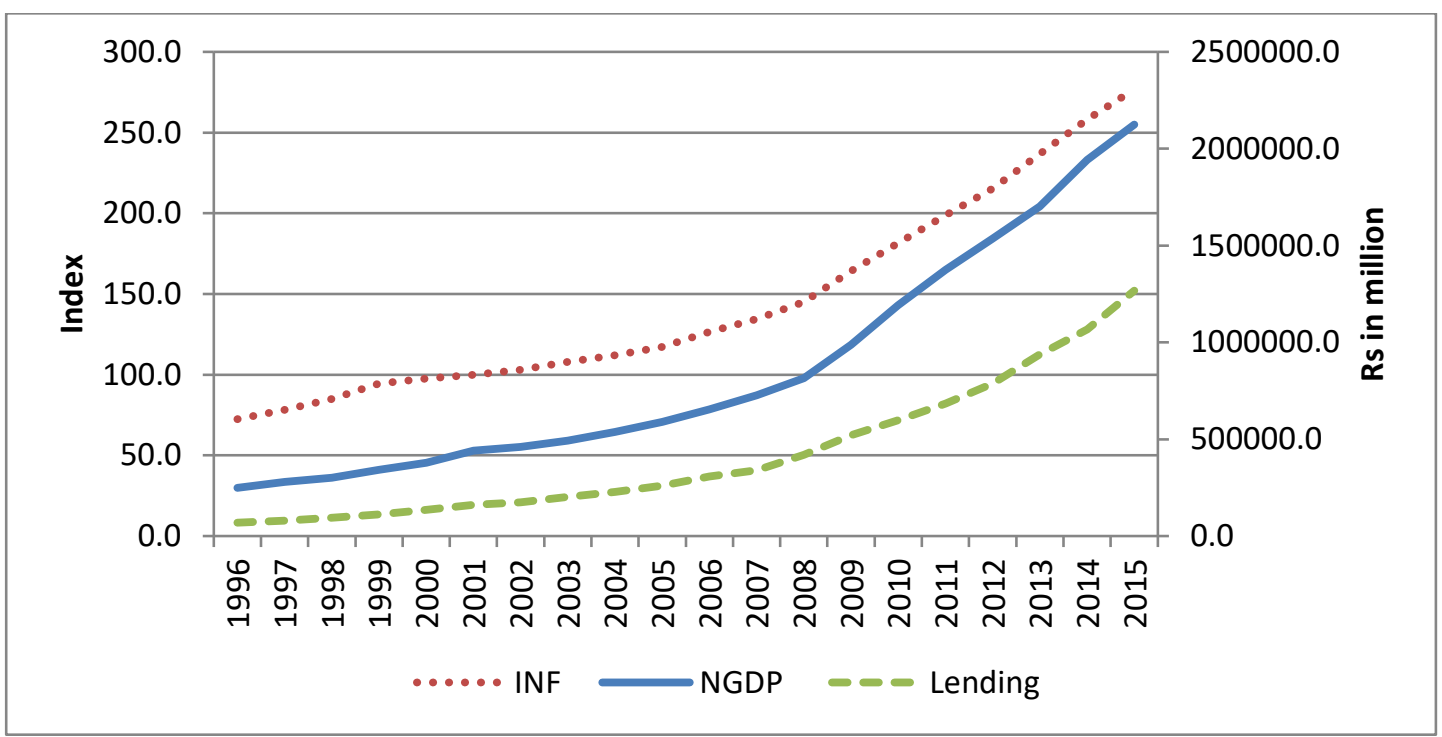

Figure 2: Relationship between bank lending and NGDP and inflation

\section{RESEARCH METHODOLOGY}

\section{Research design}

The study adopts causal-comparative research design in order to determine the effect of bank lending on inflation. While constructing model, the dependent variable is inflation and the independent variables are bank lending and interest rate.

Nature and sources of data 
This study is based on secondary data. Secondary data have been collected from commercial banks for the period 1996-2015. The main sources of secondary data are Banking and Financial Statistics, Quarterly Economic Bulletin, Monetary Policies and NRB Directives published by Nepal Rastra Bank, and the annual report and website of the selected commercial banks. Population of this study includes 30 commercial banks of Nepal listed in Nepal Stock Exchange (NEPSE) limited to the end of 2015. This study uses data of 24 commercial banks with 369 observations from 1996 to 2015.

\section{Method of analysis}

The method of analysis employed in this study consists of estimating the econometric models, and correlation analysis. The econometric models were used to examine the impact of bank lending on inflation, while correlation analysis is used to establish the relationship between dependent and independent variables used in the study.

Description of the sample for secondary data in the form of number of observations and selected companies is presented in table 4.

Table 4: Selection of commercial banks, period of study and number of observations

\begin{tabular}{|l|l|l|c|}
\hline S.N. & Name of banks & Study period & Observations \\
\hline 1 & NBL & $1996-2015$ & 20 \\
\hline 2 & RBBL & $1996-2015$ & 20 \\
\hline 3 & NABIL & $1996-2015$ & 20 \\
\hline 4 & NIBL & $1996-2015$ & 20 \\
\hline 5 & SCBNL & $1996-2015$ & 20 \\
\hline 6 & HBL & $1996-2015$ & 20 \\
\hline 7 & NSBL & $1996-2015$ & 20 \\
\hline 8 & NBBL & $1996-2015$ & 20 \\
\hline 9 & EBL & $1996-2015$ & 20 \\
\hline 10 & BOKL & $1996-2015$ & 20 \\
\hline 11 & NCCBL & $1997-2015$ & 19 \\
\hline 12 & LBL & $1997-2015$ & 17 \\
\hline 13 & NICABL & $1998-2015$ & 17 \\
\hline 14 & MBL & $2000-2015$ & 15 \\
\hline 15 & KBL & $2000-2015$ & 15 \\
\hline 16 & LXBL & $2001-2015$ & 14 \\
\hline 17 & SBL & $2002-2015$ & 13 \\
\hline 18 & ADBNL & $2007-2015$ & 9 \\
\hline 19 & GBL & $2007-2015$ & 9 \\
\hline 20 & CBL & $2007-2015$ & 9 \\
\hline 21 & PCBL & $2008-2015$ & 8 \\
\hline 22 & SBL & $2008-2015$ & 8 \\
\hline 23 & GRBL & $2008-2014$ & \\
\hline & & & 8 \\
\hline
\end{tabular}




\begin{tabular}{|l|l|l|c|}
\hline 24 & NMBL & $2008-2015$ & 8 \\
\hline & Total number of observations & Up to 2015 & $\mathbf{3 6 9}$ \\
\hline
\end{tabular}

Source: Bank and Financial Statistics, Nepal Rastra Bank

Thus, the study is based on 369 observations.

\section{Model}

This study has estimated regression model to analyze the relationship between bank lending and inflation. Hence bank lending is taken as the independent variable and inflation is the dependent variable. From these independent and dependent variables, the following relationship is formulated. It is assumed that inflation is dependent on bank lending It is represented as follows:

$\operatorname{Inf}=\mathrm{f}(\mathrm{L})$

Which shows lending is the function of monetary actions.

Where;

$\mathrm{L}=$ Lending

Inf = Inflation

\section{Model 1}

In model 1, the impact of bank lending is tested on inflation (log of inflation) with the help of regression estimates. The model is presented as:

$\ln$ inf $=\beta 0+\beta_{1} \ln$ lending $+\beta_{2}$ IR it $+\mathrm{e}$

where,

$\ln$ inf $=\log$ of inflation

ln lending $=\log$ of bank lending

$\mathrm{IR}=$ Interest Rate

Interest rate is taken as the control variable in the model.

\section{Descriptive statistics}

This study applied descriptive statistics associated with bank lending and inflation during the sample period. The descriptive statistics such as mean, standard deviation minimum and maximum values have been used to describe the characteristics of bank lending and inflation during the period of 1996 to 2015 .

\section{Correlation analysis}

Correlation analysis has been basically adopted to identify the direction and magnitude of relationship between bank lending and inflation in this study. This relationship has been explained by using Pearson correlation coefficient. The value of correlation coefficient varies from -1 to1. The coefficient of correlation of exactly -1 indicates perfect negative correlation. On the other hand, the correlation coefficient of 1 indicates perfectly positive relation.

\section{Regression analysis}

Classical linear regression model has a number of assumptions. Important assumptions are the significance of regression coefficients as well as overall significance. This study has employed tstatistic to conduct significance test of regression coefficients. A regression coefficient is said to be 
statistically significant if the critical P-value of test statistic is less than the level of significance specified. In other words, the statistical significance of the coefficient validates the explanatory power of associated independent variables. The levels of significance specified in this study are at 1 and 5 percent.

Moreover, it is necessary to test the joint hypothesis that all regression coefficients are simultaneously significant. It is called the test of overall significance of the model. This can be done by using adjusted coefficient of determination (Adj. R2) and F-statistic. The Adj. $R 2$ has been used to identify the percentage of total variation in dependent variable that has been explained jointly by all explanatory variables. The statistical significance of this joint explanatory power has been conducted by using F-statistics. The p-value of F-test has been examined to confirm whether the regression models are significant at 1 and 5 percent level.

\section{RESULTS}

\section{Descriptive statistics}

The descriptive statistics of different variables selected under the study are shown in table 5 .

Table 5: Descriptive statistics for the selected variables under the study

\begin{tabular}{|l|c|c|c|c|c|}
\hline \multicolumn{7}{|c|}{ Descriptive statistics } \\
\hline Variables & $\mathrm{N}$ & Minimum & Maximum & Mean & Std. Deviation \\
\hline Lending (Rs in millions) & 369 & 49.0 & 75774.0 & 15994.10 & 14446.7 \\
\hline IR (percent) & 369 & 4.0 & 10.0 & 5.83 & 2.01 \\
\hline Inflation (percent) & 369 & 2.4 & 13.2 & 7.73 & 2.88 \\
\hline
\end{tabular}

Table 5 shows descriptive statistics - mean, standard deviation, minimum and maximum values variables associated with 24 sample banks for the period 1996 to 2015.

Total lending of sample banks ranged from Rs. 49 million to Rs. 75774 million having an average of Rs. 15994.10 million. Likewise, IR has a minimum value of 4 percent and maximum value of 10 percent leading to the average of 5.83 percent. Inflation of Nepalese economy was 7.73 on average with a minimum value of 2.4 and maximum value of 13.2 during the study period.

\section{Correlation analysis}

This section of the study presents the results and discussions of the correlation analysis. The correlation analysis has been carried out to assess the direction and amplitude of the relationship of bank lending, inflation rate and interest rate.

Having indicated the descriptive statistics, the Pearson correlation coefficients have been computed and the results are presented in the table 6 . The table shows that there is a positive relation between bank lending and inflation where as there is a negative relationship between inflation and interest rate. It indicates that higher the bank lending, higher would be the inflation.

Table 6: Pearson's correlation matrix for the dependent and independent variables during the period 1996 to 2015. 
This table reveals the Pearson correlation coefficients between different dependent and independent variables [Lending, IR and inflation]. The correlation coefficients are based on the data from 369 observations for the period 1996 to 2015.

\begin{tabular}{|l|c|c|c|}
\hline $\begin{array}{l}\text { Variable } \\
\mathrm{s}\end{array}$ & Lending & Inf & IR \\
\hline Lending & 1 & & \\
Inf & $0.662^{* *}$ & 1 & \\
IR & $-0.117^{*}$ & $\begin{array}{c}0.214^{*} \\
*\end{array}$ & 1 \\
\hline
\end{tabular}

Note:

**. Correlation is significant at the 0.01 level (2 tailed).

*. Correlation is significant at the 0.05 level (2-tailed).

\section{Regression analysis}

\section{Regression results on the effect of bank lending on inflation is shown in table 7.}

\section{Table 7 : Regression of lending of commercial banks on Inflation (Inf)}

The results are founded on panel data of 24 commercial banks with 369 observations for the period of 1996 to 2015 by using linear regression model. Log inflation is the dependent variable while, $\log$ of bank lending and interest rate are the independent variables. The model is: $\operatorname{lninf}=\beta 0+\beta$ linlending $+\beta_{2} I R+$ error.

\begin{tabular}{|c|c|c|c|c|c|c|c|}
\hline \multirow[t]{2}{*}{ Models } & \multirow[t]{2}{*}{ Intercept } & \multicolumn{2}{|c|}{$\begin{array}{c}\text { Regression Coefficients of } \\
\text { Ininf }\end{array}$} & \multirow[t]{2}{*}{$\operatorname{Adj} R^{2}$} & \multirow[t]{2}{*}{ SEE } & \multirow[t]{2}{*}{$\mathbf{F}$} & \multirow[t]{2}{*}{ DW } \\
\hline & & Lending & IR & & & & \\
\hline 1 & $\begin{array}{l}1.23 \\
(24.92) * *\end{array}$ & $\begin{array}{l}0.24 \\
(19.18) * *\end{array}$ & & 0.50 & 0.12 & 367.88 & 0.59 \\
\hline 2 & $\begin{array}{l}2.32 \\
(91.69) * *\end{array}$ & & $\begin{array}{l}-0.03 \\
(-6.16) * *\end{array}$ & 0.09 & 0.16 & 38.0 & 0.01 \\
\hline 3 & $\begin{array}{l}1.33 \\
(22.73) * *\end{array}$ & $\begin{array}{l}0.23 \\
(17.76) * *\end{array}$ & $\begin{array}{l}--0.01 \\
(-3.10) * *\end{array}$ & 051 & 0.12 & 193.09 & 0.55 \\
\hline
\end{tabular}

Note:

1. Figures in parentheses are t-values.

2. The asterisk (**), (*) sign indicates that results are significant at 0.01 and 0.05 level of significance respectively.

3. Dependent variable is log inflation (lninf)

Table 7 shows that bank lending has positive effect on inflation but interest rate has negative impact on inflation because high bank lending leads to high increase in consumption which leads to rise in price and high interest rate leads to low consumption which leads to a decline in price. Both of these findings and expected signs are consistent with theory. These findings are consistent with the findings of Antzoulatos (1996), Bacchetta and Gerlach (1997), Ludvigson (1999), Huang and Xu (1999) and Corsetti et al. (1999), Debelle (2004) and Yunus (2004). 


\section{CONCLUSIONS}

Lending is one of the major functions of banking institution. Through this work, banks affect the stability in the economy. An excessive growth in credit can impact the price stability as well as stability of the financial system by increasing prudential risks at the micro and macro levels (Igan and Pinheiro, 2011). In analyzing the monetary transmission process, the study of impact of bank lending on inflation should be analyzed properly.

There are several studies that have been carried out on this topic in foreign countries but in case of Nepal there are not enough studies on this topic especially based on recent panel data and method. Thus, this study acts as the basis for further investigation in the area of bank lending and inflation in Nepal. This study attempts to identify whether the bank lending affects inflation. Thus the main objective of this study is to assess the effects of bank lending on inflation as well as to suggest ways of improving the bank lending to achieve price stability in Nepal.

Major conclusion of this study is that there is positive impact of bank lending on inflation in Nepal. However interest rate has negative impact on inflation. Therefore it can be recommended that central bank willing to contain inflation should curtail excessive bank lending on unproductive and speculative sector.

\section{REFERENCES}

Adedoyin and Sobodun 1996 "Commercial Banks Lending Activities in Nigeria", Nigerian Financial Review, 9(3): $36-37$.

Al-Mashat, R. \& A. Billmeier. (2007). Monetary Transmission Mechanism in Egypt. Review of Middle East Economics and Finance, 4 (3), 32-82.

Adedoyin and Sobodun (1996). Commercial Banks Lending Activities in Nigeria, Nigerian Financial Review, 9(3), $36-37$.

Amidu, M. (2006). The link between Monetary Policy and Banks Lending Behavior: The Ghanaian Case, Banks and Bank Systems, 1 (1), 38-48.

Antzoulatos, A. (1996) consumer Credit and Consumption Forecasts. International Journal of Forecasting, Vol 12, No.4, pp 439-453.

Ashcraft, A. B., (2006). New evidence on the lending channel. Journal of Money, Credit.

Arron, M. and Valev, T. (2000). International lending by U.S. banks. Journal of Money, Credit and Banking, 32, 357-381.

Bachhetta,P. and S. Gerlach (1997). Consumption and Credit Constraints: International Evidence. Vol.40, No.2, pp. 207-238.

Beaudry, P., M. Caglayan and F. Schiantarelli. (2001). Monetary instability, the predictability of prices, and the allocation of investment: An empirical investigation using U.K. panel data. American Economic Review, 91, 648-62.

Bernanke, B. S. \& M. Gertler. (1995). Inside the Black Box: The Credit Channel of Monetary Policy Transmission. Journal of Economic Perspectives, 9 (4).

Bernanke, B.S. and Blinder, A. S. (1995) Credit, Money, and Aggregate Demandll, American Economic Review, May, pp. 435-439. 
Bernanke, B. S., and Blinder, A. S. (2002). The Federal Funds Rate and the Channels of Monetary Transmission, American Economic Review, September, 901-21.

Bibow, J. (2000). The Loanable Funds Fallacy in Retrospect. History of Political Economy, Volume 14 Number 5.

Bindseil, U. (2004). Monetary Policy Implementation, Theory, Past and Present. Oxford University Press: Oxford.

Blinder, A. (1987). Credit Rationing and Effective Supply Failures. Economic Journal, Vol.97, No. 386, pp. 327-52.

Bolton, P. and Freixas, X. (2000). Equity, Bonds, and Bank Debt: Capital Structure and Financial Market Equilibrium Under Asymmetric information, Journal of Political Economy, 108(2): 324-351.

Bolton, P., and Freixas, X., 2006. Corporate Finance and the Monetary Transmission Mechanism. Review of Financial Studies, 19, 829-870.

Boyd, John H., and B.D. Smith (1997).Capital Market Imperfections, International Credit Market, and Non-convergence. Journal of Economic Theory, 73:335-64.

Brooks, P. K. (2007). Does the Bank Lending Channel of Monetary Policy Work in Turky? IMF Working Paper, 7 (272).

Brousseau, V. a. (2001). Monetary policy and fears of instability. European Central Banks Working Paper .

Chowdhury, I., Hoffman, M., and Schabert, A. (2003). Inflation Dynamics and the Cost channel of Monetary Transmission. European Economic Review 50(2006) 995-1016.

Cooper, D.R and Schindler, P.S. (2003). Business Research Methods (8th edn) McGraw-Hill: New York.

Debelle, G. (2004). Household Debt and Macroeconomy. BIS Quarterly Review pp 51-64.

Dey, Malay K. and Flaherty, Susan (2005), "Stock Exchange Liquidity, Bank Credit and Economic Growth". Paper presented at the Max Fry Conference on Finance and Development, University of Birmingham, The Business School University House, Birmingham B15 2TT.

Ehrmann, Gambacorta, Martinez-Pages, Sevestre and Worms. (2001). Financial Systems and the role of banks in monetary policy transmission in the euro area,. European Central Bank Working Paper No. 105.

Ehrmann, M. (2000). Firm size and monetary policy transmission: evidence from Ewert, 6. (2000). Analysis of Credit Marketing theory, a larger perspective (1st edition ed.). Unity Press limited.

Fry, M.J. (1988). Money, Interest and Banking in Economic Development. John Hopkins University Press.

Gambacorta, L \& D. Marques-Ibanez. (2011). The Bank Lending Channel: Lessons from the Crisis. BIS Working Papers (345).

Gambacorta, L. (2001). Bank-Specific Characteristics and Monetary Policy Transmission: The Case Italy. No.103, European Central Bank, Germany. ECB Working Paper (103). 
Genberg, H. (2000). Inflation Targeting- the Holy Grail of Monetary Policy. HEI Working Paper No. $11, \mathrm{pp} 4$.

Goohoon, K. (2009). Public Debt, Money Supply and Inflation: A Cross Country Study, IMF Staff Papers, No 56, pp. 476-515.

Hashim, Y. and A. Mamman (2014). Impact of Bank Lending on Economic Growth in Nigeria. Research Journal of Finance and Accounting, Vol.5, No.18.

Huang, Y. (1999). Inflation and Investment Controls in China: The political economy of central local relations during reform era, University of Michigan.

Igan, D. and Pinheiro. (2011, December). Credit Growth and Bank Soundness: Fast and Furious? IMF Working Paper11/278

Johnson, K.A. (2015). Analysis of the Impact of the Economic Credit on the Inflation and Economic Growth in Togo. African Journal of Marketing Management, Vol.7, No. 6, pp 69-79, July.

Juurikkala, T., A. Karas and L. Solanko. (2011). The Role of Banks in Monetary Policy Transmission: Empirical Evidence from Russia.". Review of International Economics, 19 (1).

Kashyap, A. K. \& C. J. Stein. (1995). The Impact of Monetary Policy on Bank Balance Sheets. Carnegie Rochester Conference Series on Public Policy.

Kashyap, A. K. \& C. J. Stein. (2000). What Do a Million Observations on Banks Say About theTransmission of Monetary Policy? American Economic Review, 90 (3), 407-428.

Ludvigson, S. (1999). Consumption And Credit: A Model Of Time-Varying Liquidity Constraints," The Review of Economics and Statistics, vol. 81, No.3, pp.434-447, August.

Mboweni, T.T. (2000). The Objectives of Monetary Policy, BIS Review 34, South African Reserve Bank.

Peek, J. \& E. S. Rosengren. (1995). Bank Lending and the Transmission of Monetary Policy. Federal Reserve Bank of Boston Conference Series 39. Federal Reserve Bank of Boston, USA.

Rasche, R.H., Williams, M.M. (2007). The Effectiveness of Monetary Policy. Federal Reserve Bank of St. Louis Review 89(5), 447-489.

Read, E.W. and Gill, E.K. (1989). Commercial Banking, 4th edn, New Jersey: Engle wood cliffs.

Reserve Bank of India. (2014). Report of the Expert Committee to Revise and Strengthen the Monetary Policy Framework. Mumbai: Reserve Bank of India.

Romer, C. D., and Romer D. H. (2000). New Evidence on the Monetary Transmission Mechanism. Brookings Papers on Economic Activity, 1, 149-213.

Schumpeter, J.A. (1911). The Theory of Economic Development, Oxford: Oxford University Press.

Serven, L. and and A. Solimano (1992). Private Investment and Macroeconomic Adjustment: A Survey, The World Bank Research Observer, 7 (1), 95-114.

Juurikkala,T., A.Karas and L. Solanko. (2009). The Role of Banks in Monetary Policy Transmission: Empirical evidence from Russia. BOFIT Discussion Papers . 
Urquhart, M. F. (2006). The Reaction of Bank Lending to Monetary Policy: The Jamaican Case. Working Paper .

Younus, S. (2004, June). The Impact of Monetary Policy on the Bank Portfolio in Bangladesh. Bank Parikrama .

White W.R. (2006). Is Price Stability Enough? BIS Working Paper No.205, pp 15. 